\title{
Analysis of Science and Mathematics Development of Early Childhood
}

\author{
Noorhapizah $^{1}$, Siti Aisyah ${ }^{1 *}$, Sutarto Hadi ${ }^{2}$

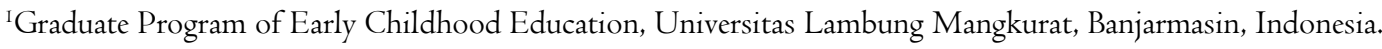 \\ ${ }^{2}$ Department of Mathematics Education, Universitas Lambung Mangkurat, Banjarmasin, Indonesia.
}

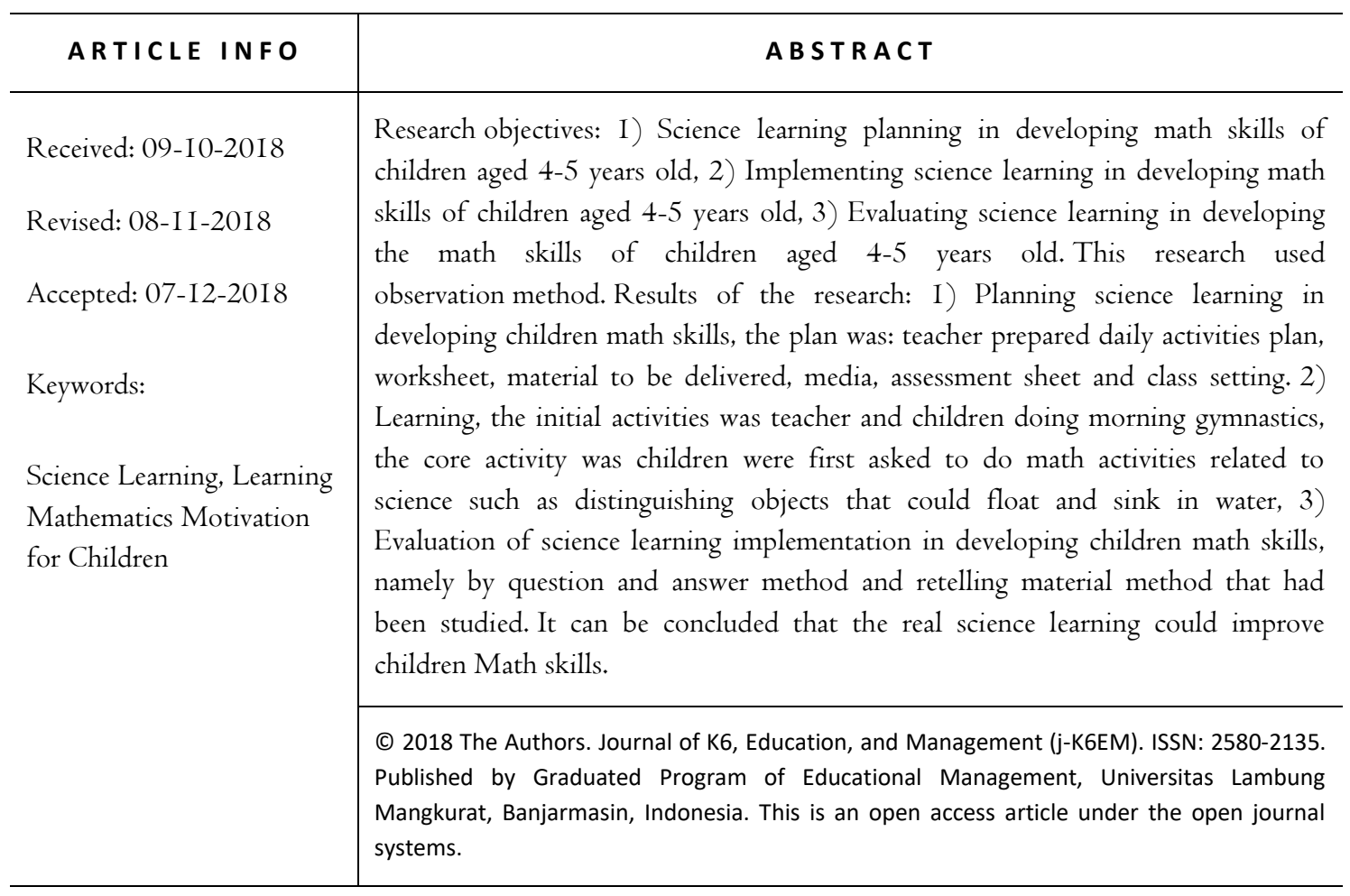

*Author correspondence: Siti Aisyah; E-mail: aisyah-siti1234@yahoo.com 


\section{Introduction}

According to (Sujiono, 2007), early childhood is the foundation of early growth and development that will then affect the next stage of life. Early childhood also requires readiness for further basic education. Arnold, Bartlett, Gowani, \& Merali (2007) explain that transition is a period of time when children are in preschool program until elementary school. School readiness is the main key to the success of school transition (Vernon-feagans \& Blair, 2006).

School readiness term is used to describe the requirements for children in order to make a successful transition from preschool to formal school (Cuskelly \& Detering, 2003). Janus et al. (2007) state that school readiness is the child skills to meet the school work requirements (Janus \& Offord, 2007). Snow (2010) adds that school readiness is a state of children competence when entering school, which is important for future success (Snow, 2010).

School readiness tends to focus on children social and academic competencies which are deemed necessary to be ready for learning (Mashburn \& Pianta, 2016). School readiness is useful for predicting achievement at the beginning of learning at school (Konold \& Pianta, 2005). Lemelin et al. (2007) state that school readiness is related to a child minimum level of development to respond to school demands through cognitive, social and emotional quality (Lemelin et al., 2007), so children who are not ready for school experience academic and behavior difficulties at school compared to their peers who are more ready for school (Konold et al., 2005). Lack of school readiness is a strong prediction of work difficulties, crime, and psychological disorders (Keating \& Hertzman, 1999).

According to Government Regulation no. 58 of 2009 on Early Childhood Education Standard, there are 3 key points in cognitive development, which are related to general knowledge and science, related to shape, color, size and pattern and related to the concept of numbers and letters.

According to (Utami et al., 2013), science is knowledge acquired through learning and proving or knowledge that covers a general truth of natural laws that occur by obtaining and proving using scientific methods. Science learning must involve aspects of knowledge, affective and psychomotor. This is in line with the opinion of (Barenthien, Lindner, Ziegler, \& Steffensky, 2018) that in realizing a quality science learning process, teachers need skills that include science-specific content knowledge (concept and inquiries) and pedagogical content knowledge.

Science is the process of thinking carried out by humans so that they get answers to everything that happens in nature and its properties. This is in line with the statement by (Andersson \& Gullberg, 20I4) that the main purpose of science learning in children is to provide an understanding of science concepts.

The method used by teachers in Science Learning in Developing Children Math Skills was field trip learning method, investigation, project-making method, experimental and exploration methods. This is in accordance with the opinion of Siry (20I2) who states that science learning in Kindergarten uses an inquiry approach, children are involved in planning, exploring and sharing ideas. Children are encouraged to collaborate with friends and learn in their own way.

Science teaching materials are arranged based on inquiry flow. Experiments conducted by children with the guidance of the teacher will become a learning experience. This is in accordance with the opinion of Paciorek (2008) who states that "children learn best when interacting in a rich environment". When children interacts with environment surrounding them, they will get a learning experience that is always attached to them. Hornby (20II) defines parental involvement as a participation in education process and experience of their children. 
According to Suyanto (2005), Science Learning in Developing Children can train them to use five senses, link cause and effect, teach them to use measuring tools, discover and understand the events and understand the concept of object and calculation.

According to Ismail (2006), children prefer teaching material composed of colored images. Results of the survey by Ade Dwi Utami (2013) on 320 teachers from 1,995 kindergarten teachers in Semarang showed that $80 \%$ of them thought that teachers experienced special obstacles in learning science and mathematics. About $80 \%$ of teachers experienced problems in selecting science and math learning strategies, $80 \%$ of teachers experienced difficulties in assessment, and $78 \%$ of teachers experienced difficulties in compiling scenarios of Science Learning in Developing Children Math Skills. Most teachers used worksheets and drawings to introduce science and mathematics. These results mean that the implementation of science and mathematics learning in kindergarten experienced problems.

The implementation of science and mathematics learning in early childhood requires careful planning. Ena Subaenah, Director General of PAUDNI (Non-Formal and Informal Early Childhood Education Programs) of Ministry of Education and Culture of 2014, stated that Science Learning in Developing Children Math Skills in early childhood has been carried out for a long time, but the implementation was still limited in terms of practice. The implementation of science and mathematics learning in early childhood experienced several obstacles related to the learning implementation. These obstacles including many children education institutions that had not taught science and mathematics and many teachers used worksheets rather than using practical tools, so students only worked on orders rather than making things. Teachers must improve learning methods to be more varied and interesting for children. Teachers shall be prepared to use fun methods such as telling stories and playing.

TK Baitul Ma'mur is one of the kindergarten institutions implementing center model and providing meaningful science and simple math experiments. TK Baitul Ma'mur was established in 2006 where TK Baitul Ma'mur implemented 6 centers, namely literacy center, preparation center, natural material center, block center, role center and Imtaq (Faith and Devotion) center. Teachers provided science and math activities in the center according to the theme taught. Then sub-theme was derived from theme to provide learning for children. For example, when the theme was learning symbol of numbers, the activities were clamping plate according to number to be learned, threading straw selected according to the number mentioned by children, counting numbers by putting the ball into the basket according to the number, counting numbers using sticks, as well as observing floating and sinking objects for science subject.

Science Learning Activities in Developing Children Math Skills were carried out before and during the center learning activities. Science experiment activity was arranged in the form of experimental activities plan. These activities help introducing children to objects used in science experiment activities and were given an understanding of the concepts in science experiment. Teacher provided an activity in the form of an experiment to dissolve some of the materials. The materials were in the form of plastic ball and stone. The children carried out an experiment by putting the ingredients in a bucket of water. $v$ introduced tools and materials and gave an explanation of events occurred during the experiment.

The school provided facilities to support the Science Learning in Developing Children Math Skills, such as buckets, water, and other supporting materials to study science and mathematics, references for experimental activities, science and math reading books, and science worksheets for children. Based on the explanation, this research discusses "Science Learning in Developing Children Math Skills at TK Baitul Ma'mur Landasan Ulin."

\section{Science Learning}

Sujiono (2007) explains that the approach to early childhood education and kindergarten learning is carried out based on a program of activities that 
have been arranged so all children behaviors and basic skills can grow at its best.

Gie (in A. Nugraha, 2006) revealed that planning is an activity that describes in advance the things that must be done and how to do it in achieving a predetermined goal. Learning implementation is an interactive activity between teachers and students that is ended with an evaluation process of learning outcomes. Learning evaluation or assessment is a way to measure the cognitive implementation, success, and development as well as the problems associated with learning outcomes expected from children (Sujiono 2007).

Juwita Yulianti (2010) in Playing While Learning Science in Kindergarten explains that science is a product and process. As a product, science is the body of well-organized knowledge about the physical and natural world. As a process, science is an activity of tracing, observing, and conducting experiments.

According to Whiterington (1979), playing has a function to facilitate the development of children cognition and allow children to see the environment, learn something, and solve the problem faced.

\section{Development of Early Childhood Math Skills}

Gardner's mathematics logical intelligence properties (Umar, 2009) states that intelligence includes three interconnected fields namely mathematics, science, and logic. In short, it is skills in mathematics development. Yus (20II) states that the mathematical logical intelligence is related to the children skills as follows: playing words, pointing and naming four to six colors, matching the same objects, drawing people with two to six known parts, and understanding the concepts of function and time.

(Sriningsih, 2009) states that mathematics learning standards refer to ten standards set by NCTM (2003), namely algebra, geometry, measurement, data analysis and probability, problem solving, reasoning and proof, communication, as well as number and operation.

\section{Definition of Simple Experiment}

Suyanto (2005) states that experiment is a very suitable thing for children in early childhood because they have a high curiosity. Children can carry out the experimental activities about observing objects that can float and sink in water. According to Roestiyah (200I), a simple experiment is one of the learning activities where children carry out experiments on a matter, conduct observation on the process, and write down the results of experiment. Djamarah (2006) states that experimental method is a way of presenting lessons where students carry out experiments and find concept of what they are learning.

Roestiyah (200I) proposes the steps of experimental method implementation namely: teacher explains the purpose of experiment, tools and materials used, teacher supervises children during activities and provides suggestions or ask questions to support children skills and collect the results of their research, opens a discussion, and evaluates them by giving a test or question and answer. According to Sudjana (2006), the steps of experimental method implementation are: preparation or planning, experiment implementation, and follow-ups.

\section{Methodology}

This research used direct research approach. The research type was observation. This research used observational study as it thoroughly explored the introduction of science through simple experiment activities in Science Learning in Developing Children Math Skills at TK Baitul Ma'mur.

\section{Research Subjects and Objects}

The subjects in this research were Teachers and Children of TK Baitul Ma'mur at Jalan Sukamara Landasan Ulin. The research object was the introduction of science and mathematics through simple experiments.

Method used in this research was descriptive method. The data were obtained by active observation, interview, and documentation. Sources of the data included (I) informants, like teachers and principal, (2) learning activities in introducing 
math and science, (3) classroom management, and (4) documents that included daily lesson plan and student learning outcomes.

\section{Results and Discussions}

To obtain a clear data about implementation of Science and Mathematics development introduction to children in early childhood at TK Baitul Ma'mur, the researchers came at the school to conduct interviews and direct observations regarding implementation of Science and Mathematics introduction learning. Observations were carried out by observing the teacher and students in doing activities. The following were general steps in the learning process applied in the classroom.

Prior to the lesson, teacher had prepared RPPM (weekly lesson plan) and RPPH (Daily Lesson Plan) in order to facilitate the learning process in accordance to 2013 curriculum that had been arranged.

\section{Mathematics and Science Learning}

The meeting wascarried out based on Daily Activity Plan (RKH) at TK Baitul Ma'mur. The theme for the day was vehicles with mathematical activity, which was an introduction to the symbol of numbers from I-IO and introduction to science with experiment activity of floating and sinking objects with the following steps:

Initial activities. To create a conducive learning condition; the children carried out motoric activities of singing before entering the class. After they did activities at the yard, they entered the classroom, then the teacher greeted them, prayed, sang the names of numbers, clapped hands about the number symbols and continued with conversation related to the theme.

When discussing the theme about land transport type such as car, teacher explained the framework of activities, types and equipment, the children were asked to observe car toy carried by the teacher, then teacher and children asked and answered questions about cars.
At the core activities, teacher introduced number IIO through several activities, namely: I) putting the ball into a basket as many as the number mentioned on the basket, 2) clamping the geometric shapes with clamps according to the number mentioned, 3) threading straws that were later given a number according to the number of straws threaded, 4) naming numbers by sticking the stick. For science activities, the teacher introduced floating and sinking objects. Teacher introduced the objects and tools used. Teacher gave an explanation before conducting the experiment. Teacher also gave answers to questions raised by children regarding the experimental activities, then the teacher exemplified activities to be carried out, explained the game rules, and arranged small groups of three students. Children were asked to do all the activities provided in turns.

In the closing activities, children sat in a circle. Teacher asked the children feelings after the game and explored their experiences after playing. Teacher concluded the activities that have been carried out. Teacher asked children to say "Alhamdulillah" (all praise is due to Allah) as a sign of gratitude after playing the game.

Teacher and children prayed before eating and children washed their hands with soap. Then they ate together. After eating the teacher encouraged children to be able to tidy up their equipment independently, praying after eating, and then the teacher invited them to play outside the classroom. During the preparatory activity, teacher invited children to gather to tell the theme/activity for the next day, then teacher invited them to sing and prayed to go home and encouraged them to be able to take their bags and personal equipment independently to take them home.

The learning stages in the classroom are as follows: initial activities, core activities and closing.

\section{Initial Activity}

Children made a circular formation in an open yard. Together with the teacher, children performed motor activities through motion and song.

At the beginning of the activity before children went to school, teachers prepared activities to be 
carried out. When they arrived, the teacher greeted and addressed the children. Children were asked to place items brought from home in the space provided. After they gathered, the teacher and children prepared and sang on the yard, conducted gross and fine motoric warm up. Early childhood development of children skills could be seen. Then the teacher must be able to stimulate the development and growth of children.

The implementation of early childhood education learning according to National Minister of Education Regulation No. 58 of 2009 (Ministry of National Education 2009) is carried out by (I) arranging the playground, and (2) organizing activities that include: (a) opening (b) core activities, and (c) closing. The learning process covers the field of behavioral and basic skills development. Development of the two fields is carried out through playing activities both indoor and outdoor as well the habituation activity. The habituation development is carried out when children arrived, played, during the transition, until the children went home. This is in accordance with a research by Pala (20II) who states that characters are not automatically formed, but are developed over time through continuous processes.

Early childhood is defined as groups of children who are in the unique process of growth and development. They have specific growth and development patterns according to their growth and development level (Mansur, 2005). According to many neurological research, it was found that 50\% of child intelligence was formed during the first 4 years. In 8 years old, brain development reached $80 \%$ and at the age of 18, it reached 100\% (Suyanto, 2005).

Elizabeth B. Hurlock (Hurlock, I978) states that motor development is defined as the development from maturity element in controlling the movement of body and brain as the center of motion. According to Daeng Sari (1996), fine motor is motoric activity that involves the activity of small or fine muscles. This movement demands eye and hand coordination and good control of motion, which enables it to carry out precision and accuracy in motion.
Kartono (1995) states that the factors influencing children motor development are heredity, environment, and children activity. Rumini (I995) states that the factors accelerating or slowing down fine motor development are genetic of individuals, health and nutrition, stimuli, protection, premature, individual abnormalities, culture, and regional regulation.

Gross motoric is the body ability to use large muscles. Most or all members of the gross motor body are needed so children can sit, kick, run, go up and go down, and so on (Sunaryo, 2007). The function of gross motor development in kindergarten children (Depdiknas, 2009) includes the following: a. Training the flexibility and coordination of finger and hand muscles. b. Encouraging the growth and development of children physical/motor, spiritual and health. c. Forming, building, and strengthening children body. d. Training skills/agility of movement and thinking of children. e. Improving children emotional development.

\section{Praying}

When praying began, not all children prayed. There were some children were silent, laughing, and smiling. Every teacher reprimanded them with a sign and there were children who understood and there were also those who ignored the warning, which made regular prayer was stopped for a moment. Not all children raised their hands. There were still those who were lazy to raise their hands, children who played their hands by rubbing on the floor, as well as children who folded their hands and used them to disturb friends next to them.

According to WJS Poerdarminta "prayer means request (wish, praise) to God." M. Arif Hakim argues that "prayer is a human effort to reach God, to communicate with an invisible being, the creator of all things, the highest wisdom, the highest truth, and the greatest power, the redeemer of the sins of every human being" (Hakim, 2004). Moral education expert Lickona mentions that there are at least 6 characters, namely: honesty, compassion, courage, kindness, self-control, and diligence. Dimerman (2009) identifies 10 
characters that must be developed, namely: respect, responsibility, honesty, empathy, fairness, initiative, courage, perseverance, optimism and integrity.

\section{Core activities}

At the core activities, children threading straws, attached sticks to the numbers and put balls in the basket, clamped geometric objects and conducted simple experiments of floating and sinking objects.

Threading activity served to develop fine motor skills of the students. The results of research at TK Baitul Ma'mur proved Jamaris' opinion that the coordination movement that can develop fine motor is to make beads or perform threading activities. This research also supports the results of research by Lestari (2016) on Effect of MediaBased Assignment Method in the Pattern Recognition Skills of Group B Children. Here, the use of straws as learning media was success to stimulate the child development other than cognitive aspect. So that there is a connection between threading activities using straw and fine motor skills of group B children at TK Baitul Ma'mur. When considering Dynamic system theory by Thelen and Smith, the research results at TK Baitul Ma'mur showed that was there was new motor skills of children in which children performed threading activities not in accordance with the direction but they created new steps to reach the goal so the strap could fit into the hole. The teacher exemplified by inserting the strap from bottom with five beads. However, there were children who did it by inserting a strap from the top of the hole, and children who threaded by licking the rope first to easily insert it into the hole.

Then there were several children who sticking the stick on the paper with number I-IO, which was useful for doing mathematics for children in early age. Aynur (20II) concludes that a good character is not formed automatically, but it is developed over time through a continuous process of teaching, model learning, and practice, this is developed through character education.

Game is one of the most important activities in life. Through game, children can learn to be active, creative, and innovate to create new things (Berk,
2008). In fact Vygotsky (in Berns, 2010) says that game is an activity that can stimulate children to recognize the rules of society, know morals, and know how to overcome various kinds of problems that occur in life. This is in line with the social competencies that illustrate children skills to control emotion and establish good relation with others (Baron \& Byrne, 1997). Playing can improve social competence, which is defined as a number of skills related to emotional recognition, adaptability, and ability to manage themselves (Xinyin, C. Dan, Li Li, \& Liu., 2000).

A research conducted by James (200I) on "Enhancing science education for young children" can be concluded as follows: The main challenge faced by teachers is how they can help children to develop the knowledge, skills and attitudes required to become the scientifically literate people.

\section{Closing activity}

In the closing activities, children sat in a circle, the teacher asked children feelings after playing and explored children experience after playing. Then teacher gave the opportunity for children to share their experiences of playing in turns, then teacher concluded the activities that had been carried out, teacher asked children to say Alhamdulillah as a sign of gratitude after playing.

The closing activity is a calming activity. Some activities that can be done in the closing include: I) Making simple conclusions from the activities that have been carried out, including the moral message to be conveyed. 2) Advices that supports good habits. 3) Reflection and feedback on the activities that have been carried out. 4) Carrying out calming activities such as singing, reciting poetry, and telling encouraging stories. 5) Informing learning plan for the following meeting.

Next is the research results on the Science Learning Implementation in Developing Math Skills of Children Aged 4-5 Years Old in Early Childhood Education at TK Baitul Ma'mur.

Planning for the Science Learning Implementation in Developing Math Skills. Interview was carried out by asking questions about Planning for the 
Science Learning Implementation in Developing Math Skills at TK Baitul Ma'mur. The researchers conducted an interview with a teacher named Mrs. Maryati who said that the planning must be prepared in advance and it consisted of making the daily activity plan (RKH); preparing learning material and learning media. In Yulianti (2010), "Playing While Learning Science in Kindergarten", the learning resource and media in Early Childhood Education were materials including equipment to provide information and skills to students and teachers to obtain and enrich the knowledge and prepare several student worksheets (LKS).

The Science Learning Implementation in Developing Math Skills. The researchers interviewed teacher. Mrs. Maryati who said that to conduct learning without any obstacles, teachers usually made rules, such as: children were not allowed to fight for the tools and toy materials, children should have not interfere their friends when studying science.

Evaluation of Science Learning Implementation in Developing Math Skills. The interview was carried out by asking questions about evaluation. The results of the interview as expressed by Mrs. Maryati. She explained that evaluation was conducted by question and answer regarding the material that had been delivered by the teacher, and during learning the teacher used a checklist to determine children cognitive development, and teacher always gave star for children work and once in a while the teacher also gave rewards to children. This is to motivate children's learning.

\section{Conclussion and Recomendations}

The planning that must be prepared is as follows, first teachers have to prepare the material namely: worksheet, daily activities plan, children's assessment sheet, class setting, and media to be used to be delivered to the students. The implementation of science learning in developing Children Math Skills among others: carrying out initial, core and final activities. Evaluation of the science learning implementation in developing Children Math Skills is carried out by question and answer or tell about the materials that have been delivered by reviewing the learning that has been taught.

It is hoped that the teachers will always carry out mathematics learning by implementing science learning so mathematics learning delivered to children will always be fun for according to their development level. As the organizers of Early Childhood Education programs, the schools should provide facilities and infrastructure for a more supportive learning process. For future researchers, since the results on the science learning implementation in developing Math skills of children aged 4-5 years are success, it is expected that future research can address the problems about mathematics with different and more interesting media.

\section{Acknowledgment}

The researchers would like to express gratitude toward the Head of Early Childhood Education Teaching Master Program and the lecturers in the Head of Early Childhood Education Teaching Master Program namely, Mr. J. Dalle, S.Pd, S.Si, M.Kom, Ph.D who had supervised the researchers since the beginning of the research until this article is complete. The researchers would also like to express gratitude toward the principal of TK Baitul Ma'mur Mr. Imam Sadikin and the board of teachers Mrs. Mariati, S.Pd. In addition, the researchers would like to express gratitude to the research team, Nopi Ariansyah, Siti Aisyah and Riska Halidah and the board of editor who provided the opportunity for the researchers to publish this research results. May all individuals who have helped and supported the researchers since the beginning of the research until the publication of this article are blessed by God the Almighty.

\section{References}

A. Nugraha, Sumama, \& A. Purwanto. (2006). Analisis Frekuensi dan Pola Dasar Frekuensi Gender Laras Slendro. Yogyakarta: FMIPA UNY. 
Andersson, K., \& Gullberg, A. (2014). What is science in preschool and what do teachers have to know to empower children? Cultural Studies of Science Education. 9(2). 275-296. https://doi.org/IO.I007/sI I422-012-9439-6

Arnold, C., Bartlett, K., Gowani, S., \& Merali, R. (2007). Is everybody ready? Readiness, transition and continuity: lessons, reflections and moving forward.

Aynur, P. (200I). The Need For Character Education. International Journal of Scocial Science and Humanity Studies.3(2). 24-34. http://www.sobiad.org/eJOURNALS/journal_IJS S/...2/aynur_pala.pdf diakses pada tanggal 26 Desember 2018.

Barenthien, J., Lindner, MA, Ziegler, T., \& Steffensky, M. (2018). Exploring preschool teachers' sciencespecific knowledge. Early Years. 5I46. I-I6. https://doi.org/I0.I080/09575I4 6.20I8.I44332 I

Baron, R.A., \& Byrne, D. (1997). Social Psychology. Massachusetts: Allyn and Bacon.

Berk, L.E. (2008). Exploring Lifespan Development. Boston: Pearson Education, Inc.

Berns, R.M. (2010). Child, family, school, community: socialization and support. California: Wadsworth.

Cuskelly, M., \& Detering, N. (2003). Teacher and Student Teacher Perspectives of School Readiness. Australian Journal of Early Childhood, 28 No. 2.

Daeng Sari, Dini, P. (1996). Metode Mengajar di Taman Kanak-Kanak. Jakarta: Depdikbud.

Depdiknas. (2009). Permendiknas No. 58/2009 tentang standar Tingkat Pencapaian Perkembangan. Jakarta: Depdikbud.

Dimerman, S. (2009). Character is The Key. Canada: Wiley.

Djamarah, Syaiful Bahri. (2006). Strategi Belajar Mengajar. Jakarta: PT Rineka.

Hakim, M. Arif. (2004). Doa Doa Terpilih Munajat Hamba Allah Dalam Suka Dan Duka. Bandung: Marja.
Hornby, G. (201 I). Parental Involvement in Childhood Education Building Effective School-Family Partnerships). XIV I37. New York: Spinger-Verlag.

Hurlock, Elizabeth, B. (1978). Perkembangan Anak. Jakarta: Erlangga.

Ismail, A. (2006). Education Games. Yogyakarta: Pilar Media.

Watters, James, J., Diezmann, Carmel M., Grieshaber, Susan J., \& Davis, Julie M. (200I). Enhancing science education for young children: A contemporary initiative. Australian Journal of Early Childhood 26(2):pp. I-7. http://eprints.qut.edu.au/ diakses pada tanggal 26 Desember 2018.

Janus, M.A., \& Offord, D.R. (2007). Development and Psychometric Properties of the Early Development Instrument (EDI): A Measure of Children's School Readiness ${ }^{\star}, 39(\mathrm{I})$, I-22. https://doi.org/I0.I037/cjbs200700I

Kartini Kartono. (1995). Psikologi Anak (Psikologi Perkembangan. Bandung: Mandar Maju.

Keating, DP, \& Hertzman, C. (Eds.). (1999). Developmental health and the wealth of nations. New York: Guilford Press.

Konold, T.R., \& Pianta, R.C. (2005). EmpiricallyDerived, Person-Oriented Patterns of School Readiness in Typically-Developing Children: Description and Prediction to First-Grade Achievement Typically-Developing Children: Description and Prediction to First-Grade Achievement, (January 20I5), 37-4I. https://doi.org/I0.1207/sI532480xads0904

Lestari, R., \& Iskandar, Dudi Sabil. (2016). Mitos Jurnalisme. Yogjakarta: Andi.

Lickona, T. (2013). Pendidikan Karakter Panduan Lengkap Mendidik Siswa Menjadi Pintar dan Baik. Terjemahan Lita S. Bandung: Nusa Media.

Mansur. (2005). Pendidikan Anak Usia Dini dalam Islam. Yogyakarta: Pustaka Pelajar.

Paciorek, K.M. (2008). Taking Sides: Clashing Views in Early Childhood Education. New York: The Mc Graw - Hill Companies. 
Pala, A. (20II). The Need For Character Education. International Journal of Social Science and Humanity Studies. 3(2). 23-32. http://www.sobiad.org/eJOURNALS/jounal_IJS S/aynur_pala.pdf diakses pada tanggal 26 Desember 2018.

Roestiyah, N.K. (200I). Strategi Belajar Mengajar. Jakarta: Rineka Cipta.

Rumini, S. \& Sundari, S. (1995). Perkembangan anak dan remaja. Jakarta: PT Rineka Cipta.

Siry, C. (2012). Towards multidimensional approaches to early childhood science education. Cultural Studies of Science Education. doi: IO.

Snow, KL (20I0). Early Education and Development Measuring School Readiness: Conceptual and Practical Considerations. (April 20I5). 37-4I. https://doi.org/I0.I207/sI5566935eedI70I

Sriningsih, Nining. (2009). Pembelajaran Matematika Terpadu Untuk Anak Usia Dini. Bandung: Pustaka Sebelas.

Sudjana, Nana. (2006). Penilaian Hasil Proses Belajar Mengajar. Bandung: Remaja Rosdakarya.

Sujiono, Y.N., dkk. (2007). Metode Pengembangan Kognitif. Jakarta: Universitas Terbuka.

Sunaryo, \& Sunardi. (2007). Intervensi Dini Anak Berkebutuhan Khusus. Jakarta: Depdiknas.

Suyanto. (2005). Konsep Dasar Anak Usia Dini. Jakarta: Departemen.

Hamzah B., Uno, \& Umar, Masri Kudrat. (2009). Mengelola Kecerdasan Dalam Pembelajaran, Sebuah Konsep Pembelajaran Berbasis Kecerdasan. Jakarta: PT. Bumi Aksara.

Utami, Ade Dwi, dkk. (2013). Modul Pendidikan dan Latihan Profesi Guru. Malang.

Utami, Ade Dwi, dkk. (2013). Modul Plpg pendidikan anak usia dini. http://sertifikasi.fkip.uns.ac.id/modul/PAU D/I\% 20PAUD.pdf.

Vernon-feagans, L., \& Blair, C. (2006). Measurement of School Readiness Measurement of School Readiness, 9289 (June). https://doi.org/I0.1207/sI5566935eedI701
Whiterington. (1979). Educational Psychology. New York: Ginn.

Yulianti, Dwi. (2010). Bermain Sambil Belajar Sains di Taman Kanak-kanak. Jakarta: PT Indeks.

Yus, Anita. (201I). Model Pendidikan Anak Usia Dini. Jakarta: Kencana Yulianti. 